\title{
Karakteristik kasus pada Visum et Repertum di RSUP dr. Soeradji Tirtonegoro Klaten 2014-2016
}

\author{
Idha Arfianti Wiraagni $^{1}$, Edy Widihartono ${ }^{2}$ \\ ${ }^{I}$ Departemen Ilmu Kedokteran Forensik dan Medikolegal, Fakultas Kedokteran, UGM \\ Jl. Farmako Sekip Utara, Yogyakarta 55281 \\ RSUP dr. Soeradji Tirtonegoro Klaten ${ }^{2}$ \\ Jl. Solo-Jogja No.1, Yogyakarta
}

Submitted: 21-06-2016

Reviewed: 02-11-2016

Accepted: 03-11-2016

\begin{abstract}
ABSTRAK
Semenjak dibukanya pelayanan forensik di RSUP dr. Soeradji Tirtonegoro Klaten pada tahun 2014, banyak kasus forensik ditangani. Berdasarkan jenis kasusnya, pada kasus mati terdapat kasus kecelakaan lalu lintas, kriminal, dan kematian lain. Pada kasus hidup, terdapat kekerasan seksual, fisik, dan psikiatri. Tujuan dari penelitian ini adalah untuk mengetahui karakteristik dasar pasien yang ada di dalam Visum et Repertum mati dan hidup. Jenis penelitian adalah studi potong lintang retrospektif, dengan metode total sampling. Data diambil dari semua Visum et Repertum yang ada di RSUP dr. Soeradji Tirtonegoro Klaten selama tahun 2014 sampai bulan Maret 2016.Terdapat 242 kasus hidup (wanita 124 orang dan pria 118 orang), serta 23 kasus mati (wanita 6 orang dan pria 17 orang). Usia korban yang paling banyak pada usia produktif (22-40 tahun), dengan korban hidup 33,5\% dan mati $30,4 \%$. Kasus yang paling banyak adalah kasus penganiayaan pada kasus hidup sebanyak 109 kasus $(45 \%)$, sedangkan pada kasus mati $100 \%$ adalah kasus kecelakaan. Profesi terbesar pada korban hidup adalah pelajar $(30,6 \%)$, sedangkan korban mati adalah sektor swasta (43,5\%). Distribusi luka mayoritas pada kepala (kasus hidup 45,9\% dan kasus mati 82,6\%). Sebagian besar pelaku pada kasus hidup tidak dikenal $77,7 \%$, begitu pula dengan kasus mati $82,6 \%$. Korban kasus forensik mayoritas adalah usia produktif. Distribusi luka terbanyak pada daerah kepala sehingga menimbulkan fatalitas besar. Pelaku yang menyebabkan perlukaan tersebut sebagian besar tidak dikenal oleh korban. Kasus yang terbesar adalah kasus penganiayaan pada korban hidup dan kasus kecelakaan pada korban mati.
\end{abstract}

Kata kunci : Visum et Repertum, karakteristik pasien, korban hidup, korban mati

\begin{abstract}
Since the opening of forensic services at RSUP dr. Soeradji Tirtonegoro Klaten since 2014, many forensic cases were handled. Based on the type of case, in the death cases, there are traffic accidents, crime, and other deaths. While in life cases, there are sexual violence, physical violence, and psychiatry. Research on basic characteristic patients' are very important to do, especially for the police, government, hospital, and community. The purpose of this study was to determine the basic characteristic patients' of Visum et Repertum in RSUP dr. Soeradji Tirtonegoro Klaten 2014-2016. This research was a crosssectional study, with a total sampling method. The data were taken from Visum et Repertum during 2014 - March 2016. There were 242 life cases (124 women, 118 men), and 23 death cases (6 women, 17 men). Most patients were productive age (22-40 years old), with $33.5 \%$ life cases and $30.4 \%$ death cases. The highest number of life cases was physical abuse (109 cases; 45\%), then all of death cases was accident. The highest profession of patients were students (30.6\% in life cases), while in the death cases were private $(43.5 \%)$.
\end{abstract}

Penulis korespondesi:

Idha Arfianti Wiraagni

Departemen Ilmu Kedokteran Forensik dan Medikolegal, Fakultas Kedokteran, UGM

Jl. Farmako Sekip Utara, Yogyakarta 55281

Email: arfianti.idha@gmail.com 
Head trauma was the most common injury in patients (45.9\% life cases and $82.6 \%$ death cases). Most of the perpetrators were unknown people (77.7\% life cases, as well as $82.6 \%$ of death cases). From both cases, the patients were from productive age, distribution of fatal wound was in the head, and the prepetators were unknown. These data are very important in educational process of society.

Keywords: Visum et Repertum, baseline characteristics, life cases, death cases

\section{PENDAHULUAN}

Semenjak dibukanya pelayanan forensik di RSUP dr. Soeradji Tirtonegoro Klaten, banyak kasus baik jenazah atau pun korban hidup ditangani di Instalasi Forensik dan Pemulasaran Jenazah RSUP dr. Soeradji Tirtonegoro Klaten. Jenis kasus yang perlu dibuatkan Visum et Repertum, adalah kasus kekerasan seksual, perlukaan, keracunan, kematian yang diduga terkait tindak pidana. Berdasarkan jenis kasusnya, pada Visum et Repertum mati terdapat kasus kecelakaan lalu lintas, kriminal, dan kematian lain. Pada Visum et Repertum hidup, terdapat kekerasan seksual, kekerasan fisik, dan psikiatri.

Kecelakaan lalu lintas merupakan masalah kesehatan yang sangat serius di dunia, masalah yang sama juga dihadapi di berbagai negara termasuk Indonesia. Di beberapa negara dengan tingkat pendapatan yang tinggi seperti di Amerika angka kematian rata-rata akibat kecelakaan lalu lintas sebesar 53,8 per 100.000 penduduk dan di Eropa 47,6 per 100.000 penduduk, sementara pada negara dengan tingkat pendapatan rendah (miskin) dan sedang angka tersebut cenderung lebih tinggi seperti di India 96,7 per 100.000 penduduk dan di negara Asia lainnya 75 per 100.000 penduduk. Di Indonesia pada tahun 2003 jumlah kecelakaan di jalan raya mencapai 13.399 kejadian dengan jumlah kematian mencapai 9.865 orang, sebanyak 6.142 mengalami luka berat, dan 8.694 luka ringan, dengan rata-rata setiap hari terjadi 40 kejadian kecelakaan lalu lintas yang mengakibatkan 30 orang meninggal dunia (WHO, 2002; Depkes RI, 2016).

Menurut Komisi Perlindungan Anak Indonesia (KPAI) selama tahun 2007, dari 555 kekerasan terhadap anak yang muncul, 11,8\% kekerasan terjadi di sekolah. Pada tahun 2008 diterapkan metode yang sama, persentasenya meningkat menjadi 39\%(KPAI, 2016). Kekerasan seksual juga semakin tinggi, 527 angka kejadian KSA (Kekerasan Seksual pada Anak) pada tahun 2007. Pada tahun 2008 angka kejadian tersebut meningkat menjadi 626, kemudian pada tahun 2009 meningkat lagi menjadi 705. Penemuan kasus kekerasan terhadap perempuan dan anak yang dimintakan Visum et Repertum pada tahun 2013 di RSUP dr.Soeradji Tirtonegoro sebesar 52 kasus, terdiri dari 22 kasus kekerasan fisik dan 30 kasus kekerasan seksual. Tahun 2014 kasus meningkat menjadi 66, terdiri dari 27 kasus kekerasan fisik dan 39 kasus kekerasan seksual. Tahun 2016 sebanyak 46 kasus, terdiri dari 17 kasus kekerasan fisik dan 29 kasus kekerasan seksual. Sebagian besar korban kekerasan seksual adalah anak-anak (Gizela, 2016).

Kasus pembunuhan sadis juga terjadi di Indonesia, diantaranya dilakukan oleh Ryan Jombang dan Robot gedeg. Tingginya tingkat kriminalitas dan kecelakaan di Indonesia saat ini menyebabkan tingginya permintaan Visum et Repertum, khususnya di RSUP dr. Soeradji Tirtonegoro Klaten. Adanya penelitian mengenai jumlah kasus dan karakteristiknya sangat penting untuk dilakukan, terutama bagi polisi, pemerintah, rumah sakit, dan masyarakat. Masyarakat bisa mendapatkan informasi yang detail, sehingga lebih meningkatkan kewaspadaan. Polisi dan pemerintah dapat merancang program preventif selanjutnya, berdasarkan atas data tersebut. Pihak rumah sakit bisa menyiapkan sarana dan prasarana yang memadai, serta untuk mengevaluasi kinerja, dalam rangka meningkatkan pelayanan bagi masyarakat (Gizela, 2016). Rumusan masalah dalam penelitian ini adalah bagaimana gambaran karakteristik dasar pasien yang ada di dalam Visum et Repertum yang ditangani di RSUP dr.Soeradji Tirtonegoro selama tahun 2014-2016, baik kasus mati maupun hidup.

\section{METODE PENELITIAN}

Jenis penelitian ini adalah penelitian deskriptif retrospektif, yang membandingkan karakteristik dasar pasien antara Visum et Repertum mati dan hidup. Metode samplingnya adalah total sampling, diambil dari semua kasus yang ada di RSUP dr. Soeradji Tirtonegoro Klaten selama tahun 2014-2016. Pengambilan data diambil dari Visum et Repertum pasien, yang berada di Instalasi Forensik dan Pemulasaran Jenazah RSUP dr. Soeradji Tirtonegoro Klaten dan Instalasi Catatan Medis. 


\section{HASIL DAN PEMBAHASAN}

Di RSUP dr. Soeradji Tirtonegoro Klaten selama tahun 2014 - Maret 2016, terdapat 242 kasus hidup (wanita sebanyak 124 orang, pria 118 orang), dan 23 kasus mati (wanita sebanyak 6 orang, pria 17 orang). Usia korban yang paling banyak pada usia produktif (22-40 tahun), dengan korban hidup 33,5\% dan korban mati 30,4\%. Kasus yang paling banyak adalah kasus penganiayaan pada kasus hidup, yaitu sebanyak 109 kasus (45\%), sedangkan pada kasus mati 100\% adalah kasus kecelakaan. Profesi terbesar pada korban hidup adalah pelajar (30,6\%), sedangkan korban mati adalah swasta (43,5\%). Distribusi luka mayoritas pada kepala (kasus hidup 45,9\% dan kasus mati 82,6\%). Sebagian besar pelaku pada kasus hidup tidak dikenal 77,7\%, begitu pula dengan kasus mati 82,6\% (Tabel I).

Untuk mendapatkan gambaran kasus yang lebih rinci, kami membagi karakteristik dasar pasien berdasarkan jenis kasusnya, yaitu : kecelakaan lalu lintas, kekerasan fisik, kekerasan seksual, dan KDRT. Kecelakaan lalu lintas adalah suatu peristiwa di jalan yang tidak disangka-sangka dan tidak disengaja melibatkan kendaraan dengan atau tanpa pemakai jalan lainnya mengakibatkan korban manusia atau kerugian harta benda (Peraturan Pemerintah no.43, 1993). Kekerasan Fisik adalah perbuatan yang mengakibatkan rasa sakit, jatuh sakit, atau luka berat. Kekerasan seksual adalah kekerasan yang terjadi karena persoalan seksualitas, termasuk perkosaan, pelecehan seksual (penghinaan dan perendahan terhadap lawan jenis), penjualan anak perempuan untuk prostitusi, dan kekerasan oleh pasangan (Undang-Undang no. 23, 2004). KDRT adalah tindakan yang dilakukan di dalam rumah tangga baik oleh suami, istri, maupun anak yang berdampak buruk terhadap keutuhan fisik, psikis, dan keharmonisan hubungan(Undang-Undang no. 23, 2004).

Tabel I. Karakteristik dasar subyek penelitian kasus hidup dan mati pada kasus visum et repertum di RSUP dr. Soeradji Tirtonegoro Klaten selama tahun 2014 - Maret 2016

\begin{tabular}{|c|c|c|c|c|c|}
\hline Variabel & $\begin{array}{c}\text { Kasus Hidup } \\
\text { N (\%) }\end{array}$ & $\begin{array}{c}\text { Kasus Mati } \\
\text { N (\%) }\end{array}$ & Variabel & $\begin{array}{c}\text { Kasus Hidup } \\
\mathbf{N}(\%)\end{array}$ & $\begin{array}{c}\text { Kasus Mati } \\
\mathbf{N}(\%) \\
\end{array}$ \\
\hline Jenis Kelamin & & & Profesi & & \\
\hline -Wanita & $124(51,24)$ & $6(26,1)$ & -PNS & $11(4,5)$ & $0(0)$ \\
\hline -Pria & $118(48,76)$ & $17(73,9)$ & -Swasta & $59(24,4)$ & $10(43,5)$ \\
\hline Usia & & & -Guru/Dosen & $1(0,4)$ & $0(0)$ \\
\hline$-<12$ tahun & $12(5)$ & $0(0)$ & -Buruh/PRT & $55(22,7)$ & $6(26,1)$ \\
\hline$-13-17$ tahun & $64(26,4)$ & $2(8,7)$ & -Pelajar & $74(30,6)$ & $3(13)$ \\
\hline$-18-21$ tahun & $29(12)$ & $3(13)$ & -Mahasiswa & $4(1,7)$ & $3(13)$ \\
\hline$-22-40$ tahun & $81(33,5)$ & $7(30,4)$ & -Tidak bekerja & $37(15,3)$ & $1(4,3)$ \\
\hline$-41-60$ tah un & $45(18,6)$ & $5(21,7)$ & Distribusi & & \\
\hline$->60$ tahun & $11(45)$ & $6(26,1)$ & Luka & $111(45,9)$ & $19(82,6)$ \\
\hline Jenis Kasus & & & -Kepala & $5(2,1)$ & $2(8.7)$ \\
\hline -Kekerasan seksual & $66(27.3)$ & $0(0)$ & -Leher & $2(0,8)$ & $0(0)$ \\
\hline -Kekerasan fisik & $109(45)$ & $0(0)$ & -Dada & $6(2,5)$ & $0(0)$ \\
\hline -KLL & $43(17,8)$ & $23(100)$ & -Perut & $43(17,8)$ & $2(8.7)$ \\
\hline -KDRT & $24(9,9)$ & $0(0)$ & -Ekstrimitas & $1(0,4)$ & $0(0)$ \\
\hline Pelaku & & & -Vagina & $2(0,8)$ & $0(0)$ \\
\hline -Keluarga inti & $24(9,9)$ & $0(0)$ & -Selaput dara & $43(17,8)$ & $0(0)$ \\
\hline -Teman/pacar & $28(11,6)$ & $0(0)$ & -Tidak ada & $1(0,4)$ & $0(0)$ \\
\hline -Tetangga & $2(0,8)$ & $0(0)$ & luka & & \\
\hline -Tidak dikenal & $188(77,7)$ & $19(82,6)$ & -Campuran & & \\
\hline -Kecelakaan tunggal & $0(0)$ & $4(17,4)$ & & & \\
\hline
\end{tabular}

\section{Kecelakaan Lalu Lintas}

Berdasarkan Tabel II, baik pada kasus hidup maupun mati, korban terbanyak adalah pria, berprofesi di sektor swasta, dan lawan kecelakaannya adalah orang yang tidak dikenal. Menurut Clarke $e t$ al. 2004, pengendara laki-laki yang berusia muda (15-24 tahun), menjadi salah satu penyebab kecelakaan lalu lintas (67\% dari total keseluruhan kecelakaan kendaraan bermotor) (Clarke et al., 2004). Hasil penelitian ini serupa dengan penelitian Kartika, 2008. Hal ini kemungkinan disebabkan karena laki-laki lebih sering mengemudikan kendaraan dengan kecepatan tinggi dibandingkan wanita, sehigga risiko terjadinya kecelakaan lalu lintas semakin tinggi (Kartika, 2008; Angela et al., 2013). Untuk usia mayoritas adalah usia produktif, hal ini karena pada rentang usia tersebut mempunyai mobilitas yang 
lebih tinggi dan kesibukan yang lebih banyak dibandingkan dengan kelompok umur yang lain. Hasil penelitian ini sama dengan penelitian pola luka yang diteliti oleh Angela et al., 2013. Serupa dengan ini, penelitian di Manado menunjukkan bahwa interval umur 15-24 tahun $(37,79 \%)$ merupakan persentase kecelakaan tertinggi (Sondakh et al., 2015).

Distribusi luka yang paling parah terdapat pada daerah kepala. Menurut penelitian yang dilakukan oleh Channabasavanna dan Gururaj, 1994; Gururaj, 1995, 60\% kematian dan perlukaan pada kepala dikarenakan kecelakaan lalu lintas. Beberapa kelainan yang sering terjadi adalah fraktur tulang kepala, kontusio serebri, dan perdarahan intrakranial. Kecelakaan pengendara sepeda motor mencapai angka 30$40 \%$ dari total kasus trauma kepala. Risiko kematian pada pengendara sepeda motor yang tidak memakai helm meningkat dua kali lipat dibandingkan dengan yang memakai helm (Channabasavanna dan Gururaj, 1994; Gururaj, 1995).

Tabel II. Karakteristik dasar subyek penelitian kasus hidup dan kasus mati kecelakaan lalu lintas di RSUP dr. Soeradji Tirtonegoro Klaten selama tahun 2014 - Maret 2016

\begin{tabular}{|c|c|c|c|c|c|}
\hline Variabel & $\begin{array}{c}\text { Kasus Hidup } \\
\mathbf{N}(\%)\end{array}$ & $\begin{array}{c}\text { Kasus Mati } \\
\text { N }(\%)\end{array}$ & Variabel & $\begin{array}{c}\text { Kasus Hidup } \\
\text { N (\%) }\end{array}$ & $\begin{array}{c}\text { Kasus Mati } \\
\text { N (\%) }\end{array}$ \\
\hline Jenis Kelamin & & & Profesi & & \\
\hline -Wanita & $15(34,9)$ & $6(26,1)$ & -Swasta & $11(25,6)$ & $10(43,5)$ \\
\hline -Pria & $28(65,1)$ & $17(73,9)$ & -Buruh/PRT & $15(34,9)$ & $6(26,1)$ \\
\hline Usia & & & -Pelajar & $7(16,3)$ & $3(13)$ \\
\hline$-<12$ tahun & $2(4,7)$ & $0(0)$ & -Mahasiswa & $1(2,3)$ & $3(13)$ \\
\hline$-13-17$ tahun & $3(7)$ & $2(8,7)$ & -Tidak bekerja & $2(4,7)$ & $1(4,3)$ \\
\hline$-18-21$ tahun & $4(9,3)$ & $3(13)$ & -PNS & $6(14)$ & $0(0)$ \\
\hline$-22-40$ tahun & $10(23,3)$ & $7(30,4)$ & -Guru/Dosen & $1(2,3)$ & $0(0)$ \\
\hline$-41-60$ tahun & $14(32,6)$ & $5(21,7)$ & Distribusi Luka & & \\
\hline ->60 tahun & $10(23,3)$ & $6(26,1)$ & -Kepala & $26(60,5)$ & $19(82,6)$ \\
\hline Pelaku & & & -Leher & $0(0)$ & $2(8,7)$ \\
\hline -Kecelakaan & $0(0)$ & $4(17,4)$ & -Ekstrimitas & $16(3)$ & $2(8,7)$ \\
\hline tunggal & & & -Perut & $1(2,3)$ & $0(0)$ \\
\hline $\begin{array}{l}\text {-Tidak } \\
\text { dikenal }\end{array}$ & $43(100)$ & $19(82,6)$ & & & \\
\hline
\end{tabular}

\section{Kekerasan Fisik}

Berdasarkan Tabel III, korban dari kekerasan fisik yang masuk ke RSUP dr. Soeradji Tirtonegoro Klaten, mayoritas adalah pria, usia produktif, distribusi luka di kepala, berprofesi di sektor swasta, dan pelakunya adalah orang yang tidak dikenal. Pada tahun 2012, sekitar 475.000 orang di seluruh dunia menjadi korban kriminalitas, dengan rata-rata 6,7 per 100.000 penduduk. Insidensi pada negara maju lebih rendah dibandingkan dengan negara berkembang. Pada negara maju terdapat rata-rata 3,8 per 100.000 penduduk (WHO, 2014).Hasil penelitian di atas sesuai dengan hasil studi epidemiologi WHO tahun 2014, yang melaporkan korban pria mencapai angka 82\% dari total kasus. Rerata per 100.000 penduduk, korban pria empat kali lebih banyak daripada wanita (10,8 wanita dan 2,5 pria). Diantara pria, mayoritas korban adalah usia produktif berusia 15-29 tahun sekitar 18,2 per 100.000 penduduk. Pada rentang usia ini, belum terdapat stabilitas emosi dan kematangan berpikir. Selain itu, terdapat banyak stresor yang berasal dari lingkungan sosial dan keluarga yang bisa mempengaruhi ketidakstabilan emosi. Kepala melindungi organ yang sangat penting yaitu otak, dimana otak mengatur fungsi dasar kehidupan. Oleh karena itu, wajar jika pelaku kekerasan fisik membidik kepala menjadi sasaran targetnya untuk melumpuhkan korbannya (WHO, 2014). 
Tabel III. Karakteristik dasar subyek penelitian kasus hidup kekerasan fisik di RSUP dr. Soeradji Tirtonegoro Klaten selama tahun 2014 - Maret 2016

\begin{tabular}{|c|c|c|c|}
\hline Variabel & $\mathbf{N}(\%)$ & Variabel & $\mathbf{N}(\%)$ \\
\hline Jenis Kelamin & & Profesi & \\
\hline -Wanita & $22(20,2)$ & -Swasta & $39(35,8)$ \\
\hline -Pria & $87(79,8)$ & -Buruh/PRT & $29(26,6)$ \\
\hline Usia & & -Pelajar & $16(14,7)$ \\
\hline$-<12$ tahun & $3(2,8)$ & -Mahasiswa & $3(2,8)$ \\
\hline$-13-17$ tahun & $14(12,8)$ & -Tidak bekerja & $18(16,5)$ \\
\hline$-18-21$ tahun & $19(17,4)$ & -PNS & $4(3,7)$ \\
\hline$-22-40$ tahun & $47(43,1)$ & Distribusi Luka & \\
\hline$-41-60$ tah un & $25(22,9)$ & -Kepala & $69(63,3)$ \\
\hline ->60 tahun & $1(0,9)$ & -Leher & $5(4,6)$ \\
\hline Pelaku & & -Ekstrimitas & $19(17,4)$ \\
\hline \multirow[t]{3}{*}{-Tidak dikenal } & $109(100)$ & -Dada & $2(1,8)$ \\
\hline & & -Perut & $5(4,6)$ \\
\hline & & -Tidak ada luka & $9(8,2)$ \\
\hline
\end{tabular}

\section{Kekerasan Seksual}

Tabel IV menyatakan bahwa data korban dari kekerasan seksual yang masuk ke IGD RSUP dr. Soeradji Tirtonegoro Klaten, mayoritas adalah wanita, usia remaja, jenis kasusnya adalah pemerkosaan anak di bawah umur, distribusi luka terbanyak pada selaput dara, berprofesi sebagai pelajar, dan pelakunya adalah orang yang tidak dikenal. Hal ini sesuai dengan prevalensi kekerasan seksual di Amerika, dimana 1 diantara 5 wanita pernah mengalami pemerkosaan atau pelecehan seksual, sedangkan pada pria 1 diantara 71 orang. Sekitar $44,6 \%$ wanita dan $22,2 \%$ pria, pernah mengalami pelecehan seksual di dalam hidupnya (Black et al., 2011). Pada penelitian yang lain, korban kekerasan seksual mayoritas adalah anak di bawah 18 tahun, 80.000 anak Amerika setiap tahunnya mengalami kekerasan seksual. Hal ini diakibatkan oleh belum stabilnya emosi remaja wanita dan kelemahan secara fisik dalam melawan pelaku. Semakin muda wanita, semakin berisiko untuk mengalami kekerasan seksual dari pria (Bonnar-Kidd, 2011).

Tabel IV. Karakteristik dasar subyek penelitian kasus hidup kekerasan seksual di RSUP dr.Soeradji Tirtonegoro Klaten selama tahun 2014 - Maret 2016

\begin{tabular}{|c|c|c|c|}
\hline Variabel & $\mathbf{N}(\%)$ & Variabel & $\mathbf{N}(\%)$ \\
\hline Jenis Kelamin & & Profesi & \\
\hline -Wanita & $63(95,5)$ & -Swasta & $2(3)$ \\
\hline -Pria & $3(4)$ & -Buruh/PRT & $5(7,6)$ \\
\hline Usia & & -Pelajar & $50(75,8)$ \\
\hline$-<12$ tahun & $7(10,6)$ & -Tidak bekerja & $9(13,6)$ \\
\hline$-13-17$ tahun & $46(69,7)$ & Distribusi Luka & \\
\hline$-18-21$ tahun & $5(7,6)$ & -Selaput dara & $25(37,9)$ \\
\hline$-22-40$ tah un & $7(10,6)$ & -Vagina & $3(4,5)$ \\
\hline$-41-60$ tahun & $1(1,5)$ & -Ekstrimitas & $2(3)$ \\
\hline Jenis Kasus & & -Tidak ada luka & $36(54,5)$ \\
\hline -Pemerkosaan dewasa & $7(10,6)$ & Pelaku & \\
\hline -Pemerkosaan anak & $37(56,1)$ & -Teman/pacar & $28(42,4)$ \\
\hline -Pencabulan suka sama suka & $17(25,8)$ & -Tetangga & $2(3)$ \\
\hline -Pelecehan seksual lain & $5(7,6)$ & -Tidak dikenal & $36(54,5)$ \\
\hline
\end{tabular}

\section{KDRT}

Pada Tabel V terdapat data dari korban KDRT, mayoritas adalah istri, usia produktif, distribusi luka terbanyak pada kepala, berprofesi di sektor swasta, dan pelakunya adalah suami sendiri. Hasil serupa didapatkan pada penelitian di Inggris, yang menyatakan $31 \%$ wanita dan $18 \%$ pria mengalami KDRT sejak usia 16 tahun, jumlah ini mencapai 5 juta pada wanita dan 2.9 juta pada pria (Ansara et al., 2011). Beberapa faktor penyebab terjadinya KDRT adalah, adanya hubungan kekuasaan yang tidak seimbang 
antara suami dan istri, ketergantungan ekonomi, kekerasan sebagai alat untuk menyelesaikan konflik, persaingan, frustasi, dan kesempatan yang kurang bagi perempuan dalam proses hokum (Ribka, 1998).

Tabel V. Karakteristik dasar subyek penelitian kasus hidup kdrt di RSUP dr. Soeradji Tirtonegoro Klaten selama tahun 2014 - Maret 2016

\begin{tabular}{ll}
\hline \multicolumn{1}{c}{ Variabel } & $\mathbf{N}(\%)$ \\
\hline Jenis Kelamin & \\
-Wanita & $24(100)$ \\
Usia & \\
-13-17 tahun & $1(4,2)$ \\
$-18-21$ tahun & $1(4,2)$ \\
$-22-40$ tahun & $17(70,8)$ \\
-41-60 tah un & $5(20,8)$ \\
Pelaku & \\
-Suami & $24(100)$ \\
& \\
\hline
\end{tabular}

\begin{tabular}{ll}
\multicolumn{1}{c}{ Variabel } & \multicolumn{1}{c}{$\mathbf{N}(\%)$} \\
\hline Profesi & \\
-PNS & $1(4,2)$ \\
-Swasta & $7(29,2)$ \\
-Buruh/PRT & $6(25)$ \\
-Pelajar & $1(4,2)$ \\
-Tidak bekerja & $9(37,5)$ \\
Distribusi Luka & \\
-Kepala & $16(66,7)$ \\
-Ekstrimitas & $6(25)$ \\
-Tidak ada luk & $2(8.3)$ \\
& \\
\hline
\end{tabular}

\section{KESIMPULAN}

Berdasarkan hasil penelitian yang dilakukan di RSUP dr. Soeradji Tirtonegoro Klaten selama tahun 2014-2016, korban kasus forensik mayoritas adalah usia produktif, baik pria maupun wanita. Distribusi luka terbanyak pada daerah kepala sehingga menimbulkan fatalitas yang besar. Pelaku yang menyebabkan perlukaan tersebut sebagian besar tidak dikenal oleh korban. Jumlah kasus yang terbesar adalah kasus penganiayaan pada korban hidup dan kasus kecelakaan lalu lintas pada korban mati.

\section{DAFTAR PUSTAKA}

Angela, Z., Tomuka, D.Ch., Siwu, J.,2013, Pola luka pada kasus kecelakaan lalu lintas di BLU RSU Prof. Dr. R. D. Kandou Manado periode 2010-2011, Jurnal e-Biomedik (eBM) 1:683.

Ansara, et al., 2011, Psychosocial consequences of intimate partner violence for women and men in canada. Journal of Interpersonal Violence:26.

Black, M.C., et al., 2011, The national intimate partner and sexual violence survey (NISVS): 2010 summary report. Atlanta GA.

Bonnar-Kidd, K., 2010, Sexual offender laws and prevention of sexual violence or recidivism. American Journal of Public Health100(3): 412-9.

Channabasavanna, S.M., dan Gururaj, G.,1994, Head injuries and helmets. implications for policies in developing countries. Journal of police research and development Jan - Mar : 19-24.

Clarke, D.,et al. 2004, Road Safety Research Report No. 54, In-depth study of motorcycle accidents. Department for Transport. London.

Depkes RI. 2016. Setiap hari 30 orang meninggal dunia akibat kecelakaan lalu lintas, Jakarta 2004. Diakses tanggal 25 April 2016.

Gizela B.A., 2016, Peran pusat pelayanan terpadu pemberdayaan perempuan dan anak (P2TP2A) dalam penanganan korban kekerasan terhadap perempuan dan anak di RSUP. dr. Soeradji Tirtonegoro Klaten, in Prosiding PIT dan Konas PDFI 2016, PDFI, Bandung.

Gururaj, G., 1995, An epidemiological approach to prevention, prehospi-tal care and rehabilitation in neurotrauma. Neurology India 43(3): 95 - 106.

Kartika, M. 2008. Analisis faktor penyebab kecelakaan lalu lintas pada pengendara sepeda motor di wilayah Depok. Fakultas Kesehatan Masyarakat Universitas Indonesia. Jakarta. 1.

Peraturan Pemerintah Nomor 43 tahun 1993 ayat 1. Diakses tanggal 25 April 2016.

Ribka, P.D. 1998, Tindakan kekerasan terhadap perempuan dalam keluarga, Hasil Penelitian di Jakarta. Program Studi Kajian Wanita, Program Pasca Sarjana Universitas Indonesia. Jakarta. 
Sondakh, S., Siwu, J., Mallo, J., 2015, Prevalensi Visum et Repertum orang hidup pada kecelakaan lalu lintas di BLU RSU Prof. Dr. R. D. Kandou Manado periode 2013.Jurnal e-Clinic (eCl)1:606-611.

Undang-undang No 23 tahun 2004. Diakses tanggal 25 April 2016.

WHO.2002, The injury chart book; A graphical overview of the global burden of injuries, Departement of Injuries and Violence Prevention Noncommunicable Diseases and Mental Health Cluster World Health Organization. Geneva.

WHO. 2014, Global Health Observatory Data Repository. Global status report on violence prevention 2014. Diakses tanggal 25 April 2016. 
